\title{
As Contribuições das Teorias da Física Quântica para a fé
}

Isidoro Mazzarollo ${ }^{1}$

\section{Introdução}

Jesus e Paulo foram os pedagogos imanentes e transcendentes da inclusão. A física quântica é a ciência que propõe a inclusão universal.

Para uma pequena conversa sobre a importância da pedagogia da inclusão propomos uma breve reflexão em torno da relação entre a religião, a espiritualidade e as teorias da física quântica. Falamos teorias da física quântica porque tomaremos as teses e os postulados e não as equações, gráficos ou estatísticas.

A espiritualidade é a fonte universal da religiosidade e é o que assegura que uma religião é verdadeira. Sem a espiritualidade, que é conexão universal, a religião se torna uma ideologia de dominação, de exploração e de tirania. Nesse campo das discussões e reflexões filosóficas, éticas e antropológicas, nos deparamos com um universo em ampla desintegração, degradação e rupturas por falta de consciência de pertença cósmica, universal, quântica e espiritual. Em suas pregações, Jesus e Paulo sugerem uma consciência de pertença cósmica, includente e universal, mas os reducionismos ideológicos, totalitaristas e megalômanos ergueram-se com força tsunâmica contra as forças do perdão, da redenção e da reinclusão propostas pelo cristianismo.

Em todos os esquemas fechados, arraigados em modelos envelhecidos, é difícil a proposta da reestruturação e da reinclusão, porque o que impera nesses esquemas ideológicos carentes de razão e fé é a exclusão, a separação e erradicação do diferente, do estrangeiro, do "impuro" e do "pagão". Os esquemas fechados sempre encontram suporte nas estruturas legalistas, jurisdicistas e preconceituosas já condenadas por Jesus e por Paulo.

$\mathrm{Na}$ linguagem popular, é muito difícil que alguém faça a distinção entre espiritualidade e religião. As pessoas acreditam que quem é muito assíduo aos ritos, rigoroso no cumprimento de normas e rubricas é, "ipso facto", muito espiritual. Isso nem sempre é verdade. A tradição bíblica é muito explícita nesse aspecto desde os primeiros profetas clássicos do VIII século antes de Cristo, de modo particular os profetas Amós e Isaías. Esses profetas tinham a clarividência de que o rigor dos ritos religiosos podia esconder ou maquiar falsidades éticas, políticas ou econômicas (cf. Am 6,1-7; Is 1,10-20).

A profundidade e a veracidade de uma prática religiosa, necessariamente se transforma em espiritualidade e o espírito unifica as criaturas. Paulo afirma que os dons são múltiplos, mas o Espírito é um só, como na carta de São Paulo aos Coríntios (cf. 1Cor 11,1-11)

\footnotetext{
${ }^{1}$ Frei Isidoro Mazzarollo é teólogo e doutor em teologia bíblica pela PUC - Rio e PhD pela École Biblique et Archéologique francaise de Jerusalém, membro da ABIB (Associação Brasileira de Pesquisa Bíblica), parecerista científico de diversos periódicos nacionais de teologia e membro da Comissão do INEP que elabora o processo do ENAD, em teologia. Possui vasta publicação em sua área de pesquisa e assessoria. Citamos seu trabalho relacionado ao tema deste artigo: JESUS E A FíSICA QUÂNTICA, publicado em 2011.
} 


\section{Identidade, Alteridade e Unidade}

O texto de Paulo tem três pilares muito claros, sábios e que nos interessam muito na relação entre fé e ciência. Na metáfora dos dons e da sua unidade em torno do Espírito, percebemos três dimensões de todas as relações no cosmos: identidade, alteridade, unidade.

A. Identidade: cada dom confere a uma pessoa a sua absoluta e inegável identidade. Os dons revestem o ser humano como uma roupagem única e o caracterizam, identificam e o distinguem de todas as outras criaturas. A física quântica tem um posicionamento semelhante quando se refere à célula. Cada célula possui o seu DNA e é distinta de todas as outras milhões de células integradas no mesmo corpo. Não há duas células iguais, portanto cada uma é uma e não há confusão.

B. Alteridade: cada membro do corpo possui a sua individualidade, logo ele é distinto do outro, ele é um "alter", isto é, diferente, próprio e constituído de características específicas. A alteridade é o princípio da diversidade de funções, lugares, gostos, cores e amores. Nos postulados da física quântica acontecem os mesmos parâmetros de proximidade e distinção. O DNA distingue uma célula da outra e a torna diferente, com suas características e funções próprias.

C. Unidade: a unidade não é sinônimo de uniformidade, mas de integração do diferente, do específico e próprio. Paulo, na sua metáfora sobre os membros do corpo queria referir-se aos membros de uma comunidade cristã. Ninguém jamais vai encontrar outro igual a si mesmo, numa família, numa sociedade ou no universo. Cada um é único, mas não é independente e nem pode negar sua dependência dos outros. A unidade, nas teses da física quântica, é a formação da rede cósmica, universal que integra todas as criaturas e todos os seres como células de um único organismo vivo.

$\mathrm{Na}$ teologia de Paulo o que une todos os carismas que se manifestam de modos diferentes e exuberantes nas criaturas é o Espírito porque ele está presente em cada criatura e faz frutificar de modo diferente os dons que nela se encontram. O Espírito é que conecta a diversidade e a transforma em unidade. Segundo a física quântica, a rede, nas suas interligações, conecta todas as malhas e células.

A importância da distinção entre espiritualidade e religião é porque sem ela, qualquer ato ritualista ou devocional pode ser entendido como espiritualidade. A espiritualidade é um lastro cósmico, é a força do Espírito como bem caracteriza Paulo no texto acima (1Cor 12,114). Paulo afirma que todos os dons estão conectados pelo mesmo e único Espírito, e com isso formam um só corpo. A espiritualidade procede do Espírito e por isso Paulo usa a expressão pneymatikói (espirituais - Mazzarolo, 213, 172). O pneymático está ligado ao espiritual, ao divino, ao transcendente, que diz respeito à alma. Essa fenomenologia era muito bem 
conhecida pelos Coríntios (Bauer, pneymatikós,1971). Os "espirituais" estão, neste caso, em contraposição aos "carnais" (sarkínoi, 1Cor 3,1-3), pois os carnais assumem um comportamento infantil, imaturo e pouco consciente da sua missão e responsabilidade.

A relação ou a distinção entre religião e espiritualidade é uma provocação imperativa, uma interpelação para uma integração entre a ciência e a fé atual, uma fé madura e integradora de todos os seres humanos com seus talentos, dons e qualidades, mas também revestidos da máxima responsabilidade em todas as fases do seu comportamento e ação.

Na relação entre ciência e fé, observamos que as teorias da Física Quântica podem ser muito úteis para uma reflexão teológica atual, quer sob o prisma de uma nova visão do ser humano no universo, quer sob a perspectiva de responsabilidade nas relações humanas. $A$ Física Quântica encontra na pedagogia de Jesus um grande reforço para a superação das barreiras religiosas e dos paradigmas de exclusão causados por teorias teológicas carentes de espiritualidade.

\section{A narrativa da Criação e a Física Quântica}

No aspecto bíblico, já o relato mais antigo da Criação (Gn 2,4b-25) ao narrar a metáfora do discernimento através das duas árvores do centro do Jardim (a árvore do Conhecimento e a árvore da Vida) está afirmando que o ser humano é um "inquilino" no cosmos e deve respeitar a natureza como um todo, compreendendo as criaturas existentes como "células vivas", integrantes dessa magnífica obra da Criação de Deus (Mazzarolo, 2013, 106-132). É maravilhosa a sabedoria presente no texto bíblico, que coloca o ser humano na condição de "administrador" do cosmos, mas também ao descrever a sua natureza o colocam na mesma condição de todas as outras criaturas, isto é, ele é "feito do pó da terra" assim como toda a natureza (Cf. Gn 2,7; 3,19).

Essa consciência da própria natureza mostra o senso de pertença e também de limitação. A Física Quântica postula que o ser humano tem os "pés" na terra e o seu intelecto supranatural voltado para a abertura ao infinito (Goswami, 2007, 124). Conforme o Gênesis, o ser humano é barro iluminado por uma centelha de infinito divino, o "hálito" (ruah) divino. (Gn $2,7)$. As teses de uma relação direta entre a forma do corpo humano e a sua relação de ligação entre o mundo inferior e o mundo superior remontam às civilizações mais antigas que conhecemos. Desde as religiões herméticas já encontramos o lema: "Conhece-te a ti mesmo e conhecerás o Universo e os deuses" (Souzenelle, 1995, 15)

\section{A pedagogia de Jesus, a Fé e a Física Quântica}

A fé depende do Espírito e da dinâmica interior de uma pessoa. Jesus, na sua pedagogia da inclusão e restauração das "células mortas" na sociedade do seu tempo, fez revigorar a verdadeira fé para a transformação. O poder da fé e a força quântica da mente nunca estiveram tão manifestos quanto na pedagogia de Jesus (Mazzarolo, ${ }^{2} 2013^{2}, 106$ ). 
Jesus assegurou aos discípulos que o poder da fé seria capaz de "transportar montanhas" (LC 17,5-6), do mesmo modo que ele se impôs diante de muitas situações complicadas, como "as ondas bravias do mar" (Mc 4,35-41 e par.). Jesus despertou a fé que permitia às pessoas reconhecerem-se como dignas e destinatárias da misericórdia e da compaixão de Deus. Assim, com a mulher hemorroíssa, aconteceu que, ao ver Jesus passar, sentiu sua oportunidade de sair da exclusão e recomeçar outra vez. Decidiu romper todos os preconceitos da religiosidade e da cultura da época e aproximar-se e tocar em Jesus tendo a certeza de sua mudança se assim o fizesse (Mc 5,25-34). Nesse episódio a religião fica em segundo plano e entram os conceitos de fé e física quântica: a autopoésis ${ }^{2}$ como novo padrão ético e religioso (Mazzarolo, $\left.{ }^{2} 2013^{2}, 124\right)$.

A nova consciência ética despertada por Jesus despertou também uma fé mais viva e mais forte confirmada por uma espiritualidade integrada, na qual a conexão é fundamental, uma rede dialógica entre todas as pessoas, independente de classe, etnia, religião ou estrato social. Pedagogia semelhante vai ser desenvolvida no quadro das eclesiologias posteriores por Paulo (cf. Gl 3,28; Rm 10,12; Cl 3,11). E dentro desses novos paradigmas, o primeiro grande passo na pedagogia da inclusão de Jesus Cristo foi considerar qualquer pessoa criatura de Deus e, uma vez vinculados ao mesmo Deus, caracteriza-se como seu filho e herdeiro das promessas e com o compromisso de construir a fraternidade universal (Cf. Ef 4,6). Jesus reconciliou os circuncisos e os incircuncisos, derrubando as "paredes" da separação e unindo a todos num só povo, pois, por seu intermédio unificou judeus e gentios num só Espírito e ao redor de um só Pai (Cf. Ef 2,11-18).

A questão fundamental do ser humano é reencontrar sua identidade primeira, ontológica, um caminho de espiritualidade fundante, que o potencializa e disponibiliza para as relações de integração consigo mesmo e com toda a Criação. A espiritualidade está no santuário do ser, mesmo sem uma fórmula explícita de religião. O diálogo com a Samaritana é explícito: Nem aqui, nem em Jerusalém, mas em Espírito e Verdade (Jo 4,21). O apóstolo Paulo afirma que a Lei do Espírito é vida $(R m 8,2)$ e ela impulsiona para a paz $(R m 8,6)$, pois só o amor constrói $(1$ Cor 8,1). O que vem do Espírito, vem do alto e conduz tudo para cima, por isso, aquele que é espiritual constrói a sua felicidade na justiça e na paz com o seu próximo e com Deus (Jo 3,30-32). É nessa perspectiva que alguém pode chamar a Deus de Abba, Pai $(R m 8,15)$. E quem encontra o Pai, também encontra o seu irmão, pois encontra o caminho do amor e pratica os seus mandamentos (1Jo 2,5).

A espiritualidade é o "gene de Deus" presente em cada criatura, quer ele professe uma religião ou não. Sem a espiritualidade, a religião pode ser apenas compreendida como o

\footnotetext{
${ }^{2}$ Autopoiese ou autopoiesis (do grego auto "próprio", poiesis "criação") é um termo cunhado na década de 1970 pelos biólogos e filósofos chilenos Francisco Varela e Humberto Maturana para designar a capacidade dos seres vivos de produzirem a si próprios.Segundo esta teoria, um ser vivo é um sistema autopoiético, caracterizado como uma rede fechada de produções moleculares (processos), onde as moléculas produzidas geram com suas interações a mesma rede de moléculas que as produziu.
} 
"meme", a tradição cultural, o que se transmite de geração em geração, através da família, da educação e dos conhecimentos. (cf. Hamer, 2005, 35-45). A espiritualidade é a força que fecunda e dá sentido à religião e, ao mesmo tempo, conecta todas as mais diversas expressões religiosas, assim como o agápê é a dynamis de todos os gestos amorosos de resgate do que está em crise, e reinclusão de tudo o que foi excluído em razão de preconceitos, códigos culturais ou convenções sociais distorcidas.

A espiritualidade se caracteriza pela dinâmica da integração do ser na rede universal dos seres que não se caracterizam por cores, credos e culturas, mas se entendem numa busca universal da justiça, da paz e da prosperidade, sem discriminações, segregações e classes.

\section{Bibliografia}

BAUER, W. Wörterbuch zum Neuen Testament, Berlin, de Gruyter, 1971.

GOSWAMI, A., O universo autoconsciente: como a consciência cria o mundo material, São Paulo, Aleph, 2007.

HAMER, Dean, O Gene de Deus como herança genética pode determinar a fé, São Paulo, Mercuryo, 2005.

MAZZAROLO, Isidoro, Gênesis 1-11, E assim tudo começou... Rio de Janeiro, Mazzarolo editor, ${ }^{2} 2013$.

---- Jesus e a Física Quântica, Rio de Janeiro, Mazzarolo editor, ${ }^{2} 2013^{2}$.

---- Primeira Carta aos Coríntios, Exegese e Comentário, Rio de Janeiro, Mazzarolo editor, 2013.

SOUZENELLE, A., de, O simbolismo do corpo humano: da árvore da vida ao esquema corporal, São Paulo, Pensamento, 1995.

\section{Para refletir:}

1. Comentem e apresentem suas reflexões sobre a afirmação do autor: "Em suas pregações, Jesus e Paulo sugerem uma consciência de pertença cósmica, includente e universal, mas os reducionismos ideológicos, totalitaristas e megalômanos ergueram-se com força tsunâmica contra as forças do perdão, da redenção e da reinclusão propostas pelo cristianismo."

2. Qual a relevância da afirmação a seguir para os nossos tempos? - A nova consciência ética despertada por Jesus despertou também uma fé mais viva e mais forte confirmada por uma espiritualidade integrada, na qual a conexão é fundamental, uma rede dialógica entre todas as pessoas, independente de classe, etnia, religião ou estrato social. 
